\title{
A Prospective Comparative Study between Dry and Wet Tympanoplasty
}

\author{
Hepsiba Pothala $\quad$ Sunita Chhapola Shukla ${ }^{2}$ Wasim Khan ${ }^{1}$ Ravi Ramalingam ${ }^{1,3,4}$ \\ Kombupalayam Komarappa Ramalingam ${ }^{1,3,4}$
}

\footnotetext{
${ }^{1}$ Department of Otorhinolaryngology, KKR ENT Hospital and Research Institute, Chennai, Tamil Nadu, India

${ }^{2}$ Mumbai Port Trust Hospital, Mumbai, Maharashtra, India

${ }^{3}$ KKR ENT Super Specialty Hospital, Chennai, Tamil Nadu, India

${ }^{4}$ Chinnammal ENT Medical Education and Research Foundation,

Chennai, Tamil Nadu, India
}

\begin{abstract}
Address for Correspondence Ravi Ramalingam, MBBS, DNB, FRCS, MS Department of Otorhinolaryngology, KKR ENT Hospital and Research Institute, \#274, Poonamallee High Road, Kilpauk, Chennai 600010, Tamil Nadu, India (e-mail: kkrenthospital@gmail.com).
\end{abstract}

\begin{abstract}
Keywords

- chronic suppurative otitis media

- dry ear

- wet ear

- tympanoplasty

Background Tympanoplasty is the well-established procedure for closure of perforations of tympanic membrane.

Study Design This study was a prospective comparative study.

Objective The objective of this study was to compare the hearing improvement and graft uptake rate between dry and wet tympanoplasty performed on tubotympanic type of chronic suppurative otitis media.

Materials and Methods One hundred forty patients with tubotympanic type of chronic otitis media were selected and categorized into dry and wet ears. Tympanoplasty was performed using temporalis fascia by underlay technique in all cases. Postoperatively, graft uptake rate and hearing improvement were analyzed.

Results The graft uptake rate was equal in both dry and wet ears, which was statistically insignificant. There was no statistically significant difference in the hearing improvement between the dry ears and wet ears ( $\chi=2.39, p=0.122$ ).

Conclusion Factors such as age, sex, and status of the contralateral ear and wet ear did not have any impact on the postoperative graft uptake of tympanoplasty. There was no difference in the graft uptake between the dry and wet ears and there was no statistically significant difference between hearing improvement in both and wet ears.
\end{abstract}

\section{Introduction}

Chronic suppurative otitis media is a common disease of the pars tensa or pars flaccida, most likely a result of earlier acute otitis media, negative middle ear pressure, or otitis media with effusion affecting $0.5 \%$ to $30 \%$ of the community. ${ }^{1}$ Along with tympanic membrane perforation, there may be associated features such as aural polyp, congested and edematous middle ear mucosa. Clinically, it is divided into two types: tubotympanic and atticoantral. The aim of surgical treatment is to control infection, eliminate ear discharge, to correct hearing loss, and to prevent recurrence. ${ }^{2}$

Tympanoplasty is an operation to eradicate disease in the middle ear and to reconstruct hearing mechanism. It may be combined with mastoidectomy if disease process so demands. Type of middle ear reconstruction depends on the damage present in the ear. Myringoplasty is limited only to the closure of perforation of the tympanic membrane without inspection of the middle ear. The success rate of surgery depends on many factors such as site of perforation, condition of the ear (dry or wet), status of the contralateral ear, graft material used, Eustachian tube function, surgical techniques and associated pathologies such as adenoiditis, tonsillitis, sinusitis, and postoperative care.

Tympanoplasty can be performed on dry or wet perforations. Dry central perforation means ear should be dry for at least 6 weeks and tympanic membrane remnant should be of normal color with normal middle ear mucosa. Wet perforation means congestion of drum remnant, congestion of middle ear mucosa, presence of mucoid discharge in middle ear, and polypoidal or mucosal hypertrophy of middle ear mucosa. 


\section{Aim of the Study}

This study aimed to compare the hearing outcome and graft uptake rate between dry and wet tympanoplasty performed on tubotympanic type of chronic suppurative otitis media.

\section{Materials and Methods}

This was a longitudinal, prospective, and comparative study conducted between April 2016 and April 2018, at the KKR ENT Hospital and Research Institute, Chennai. The sample size was calculated by following formula:

$$
\text { Sample size } \begin{aligned}
n & =2(\alpha+\beta)^{2} \sigma^{2} \\
& =137\left(\text { confidence level 95\%) }\left(\mu_{1}-\mu_{2}\right)^{2}\right.
\end{aligned}
$$

$\alpha: 0.05-0.96, \beta: 0.80-0.84, \mu 1: 13.6, \mu 2: 15.2, \sigma:$

4.72 population variance reference -Hosney et $\mathrm{al}^{3}$

One hundred forty patients suffering from chronic suppurative otitis media with tubotympanic type of disease were selected.

\section{Inclusion Criteria}

1. Age between 15 and 60 years, with good general physical condition.

2. Patients with small/medium/large/subtotal perforation in pars tensa.

3. Patients with pure conductive hearing loss with intact ossicular chain intraoperatively.

\section{Criteria for Dry Ear}

a. The ear should be dry for at least 6 weeks.

b. Tympanic membrane remnant should be of normal color with normal middle ear mucosa.

\section{Criteria for Wet Ear}

a. Congestion of tympanic membrane remnant.

b. Congestion of middle ear mucosa.

c. Presence of mucoid discharge in the middle ear and polypoidal or mucosal hypertrophy of middle ear mucosa.

\section{Exclusion Criteria}

1. Patients with total perforation, evidence of cholesteatoma, squamous epithelium in the middle ear, polyps, and ossicular erosion.

2. Patients with sensorineural hearing loss.

3. Patients with ossicular fixity and/or requiring ossicular chain reconstruction or mastoidectomy.

The study was conducted after the approval of Institutional ethical and scientific committee. Study proforma included details of the patients, chief complaints, duration and type of ear discharge, preoperative audiogram, intraoperative findings, surgery performed and postoperative follow-up in terms of graft uptake, hearing improvement, and presence of complications such as facial nerve palsy, change in taste and tinnitus at third month, sixth month, and 1 year. Detailed history was taken followed by clinical examination for all patients. Patients were informed about the nature of the disease and treatment options. Informed written consent was taken from all patients. Routine blood investigation, $\mathrm{X}$-ray mastoid, pure tone audiogram, and pre-anesthetic evaluation were done for all cases. Local anesthesia was usually preferred, and general anesthesia was given for children and apprehensive patients. In both forms of anesthesia, local anesthesia of $2 \%$ lignocaine with 1 in 1,00,000 adrenaline was injected in the post aural region and in the external auditory canal. Tympanoplasty was done by post aural approach and temporalis fascia was used as the graft material by underlay technique. Follow-up was done on first, third, sixth, and 12 months for graft uptake and audiogram (-Figs. 1 and 2 ).

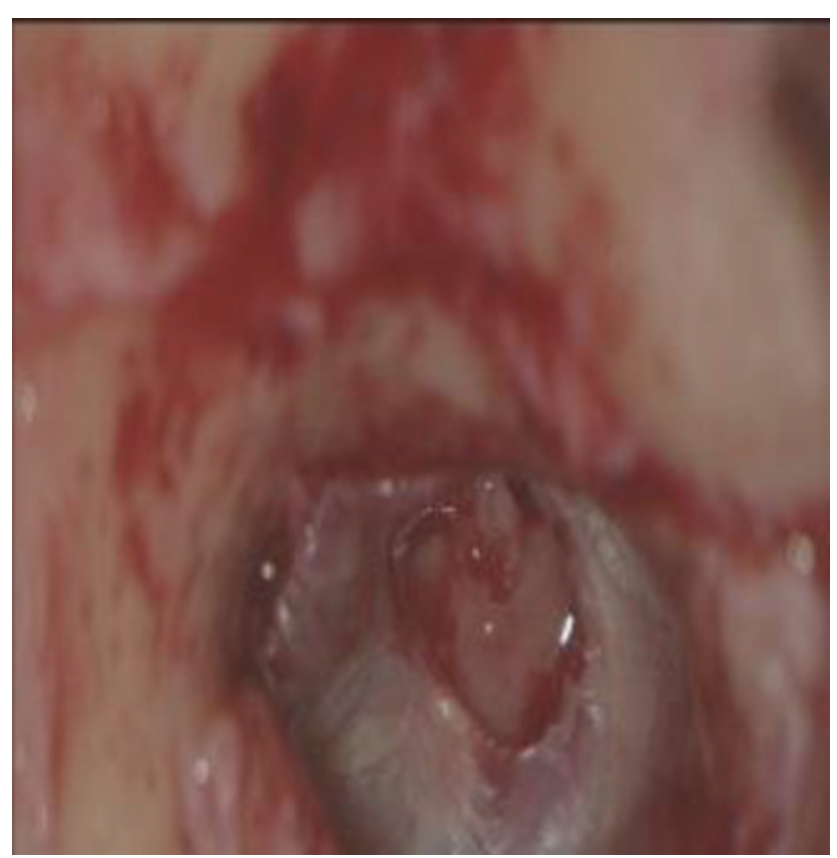

Fig. 1 Perforation with handle of malleus.

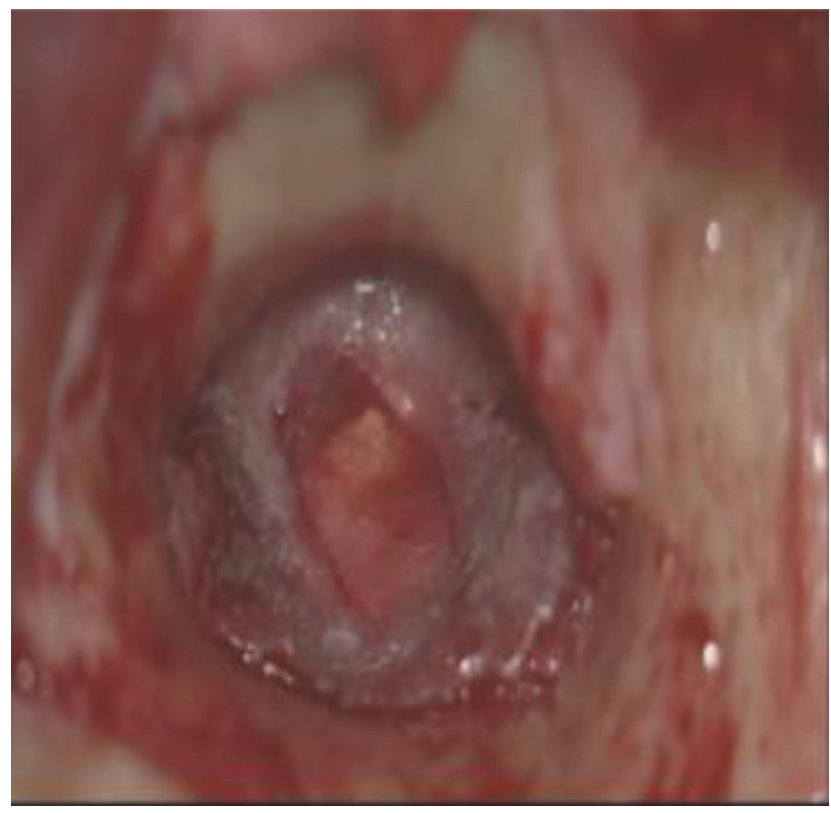

Fig. 2 Closure of perforation with temporalis fascia. 
Statistical Analysis: All patient's data were collected and statistically tested by Friedmann test, $p$-values and $\chi$.

\section{Results}

Out of 140 patients, 65 were males and 75 were females with male: female ratio of $1: 1.1$. The maximum number of patients was equal in the age group of 21 to 30 years, 31 to 40 years, and 41 to 50 years with 33 patients in each of these age groups, 28 patients in 51 to 60 years age group and 13 patients in 15 to 20 years age group.

One hundred thirteen (80.7\%) cases had unilateral disease and 27 (19.3\%) had bilateral chronic suppurative otitis media. In 27 cases of bilateral chronic suppurative otitis media, the contralateral ear was found to have wet perforation in 17 cases (63\%) and dry perforation in 10 cases (37\%).

Majority of the patients presented with complaints of ear discharge, decreased hearing, ear pain, ear block, tinnitus and giddiness (-Table $\mathbf{1}$ ).

Of the 140 patients in this study, there were 70 dry cases and 70 wet cases with a ratio of $1: 1$. Based on the size of perforation, patients were categorized into four groups. There were 25 patients (18\%) with small perforation, 62 cases (44\%) with moderate perforation, 48 cases (34\%) with large perforation, and 5 patients with subtotal perforation (4\%).

- Table 2 and 3 show the duration of perforation of dry and wet cases (-Tables $\mathbf{2 - 4}, \mathbf{-}$ Fig. $\mathbf{3}$ ).

Table 1 Distribution of ear symptoms

\begin{tabular}{|l|l|l|}
\hline Symptoms & Cases & Percentage \\
\hline Ear discharge & 111 & $79 \%$ \\
\hline Decreased hearing & 93 & $66 \%$ \\
\hline Ear pain & 58 & $41 \%$ \\
\hline Tinnitus & 20 & $14 \%$ \\
\hline Giddiness & 4 & $6 \%$ \\
\hline Ear block & 25 & $18 \%$ \\
\hline
\end{tabular}

Table 2 Preoperative dry period in dry cases

\begin{tabular}{|l|l|l|}
\hline Duration (wks) & Cases & Percentage \\
\hline $6-12$ & 12 & $17.1 \%$ \\
\hline $13-20$ & 8 & $11.4 \%$ \\
\hline $21-28$ & 20 & $28.6 \%$ \\
\hline $29-37$ & 6 & $8.6 \%$ \\
\hline$>37$ & 24 & $34.3 \%$ \\
\hline
\end{tabular}

Table 3 Preoperative wet period in wet cases

\begin{tabular}{|l|l|l|}
\hline Duration (wks) & Cases & Percentage \\
\hline $5-8$ & 12 & $17.1 \%$ \\
\hline $9-12$ & 13 & $17.6 \%$ \\
\hline $13-16$ & 10 & $14.3 \%$ \\
\hline$>16$ & 35 & $50 \%$ \\
\hline
\end{tabular}

\section{Graft Uptake}

In the present study, out of 70 dry ears, there was graft uptake in $69(98.58 \%)$ cases with one patient having reperforation in the third month. Out of 70 wet ears, there was graft uptake in $69(98.58 \%)$ cases with one patient having perforation in the fourth month. Hence, there was no difference in the graft uptake between the dry ears and wet ears.

\section{Postoperative Hearing}

Postoperatively, patients were followed up at one month, third month, sixth month, and 1 year to check the status of the ear. Postoperative audiogram was taken at third month, sixth month, and 1 year. In the present study, the hearing improvement was judged by closure of $A B$ gap equal to or more than $10 \mathrm{~dB}$.

The mean preoperative $A B$ gap and postoperative $A B$ gap in dry ears was $28.6 \mathrm{~dB}$ and $11.3 \mathrm{~dB}$, thus showing $A B$ gap closure of $17.3 \mathrm{~dB}(p=0.0001)$, which was statistically significant.

The mean preoperative $A B$ gap and postoperative $A B$ gap in wet ears was $29.6 \mathrm{~dB}$ and $14.4 \mathrm{~dB}$, thus showing $A B$ gap closure of $15.2 \mathrm{~dB}(p=0.0001)$, which was statistically significant (-Tables $\mathbf{5}, \mathbf{6}$ ).

There was no statistically significant difference in the hearing improvement between the dry ears and wet ears $(\chi=2.39, p=0.122)$.

Out of nine patients in dry ears, who did not have hearing improvement, one patient had lateralized drum, three patients had upper respiratory tract infections (two patients with

Table 4 Preoperative AC threshold in dry and wet ears

\begin{tabular}{|l|l|l|l|l|}
\hline \multirow{2}{*}{$\begin{array}{l}\text { Preoperative } \\
\text { AC threshold }\end{array}$} & \multicolumn{2}{|c|}{ Dry ears } & \multicolumn{2}{c|}{ Wet ears } \\
\cline { 2 - 5 } & Cases & Percentage & Cases & Percentage \\
\hline $0-10 \mathrm{~dB}$ & 0 & 0 & 0 & 0 \\
\hline $11-20 \mathrm{~dB}$ & 0 & 0 & 0 & 0 \\
\hline $21-30 \mathrm{~dB}$ & 19 & 27.1 & 17 & 24.3 \\
\hline $31-40 \mathrm{~dB}$ & 27 & 38.5 & 27 & 38.6 \\
\hline $41-50 \mathrm{~dB}$ & 16 & 23 & 17 & 24.3 \\
\hline $51-60 \mathrm{~dB}$ & 8 & 11.4 & 9 & 12.8 \\
\hline
\end{tabular}

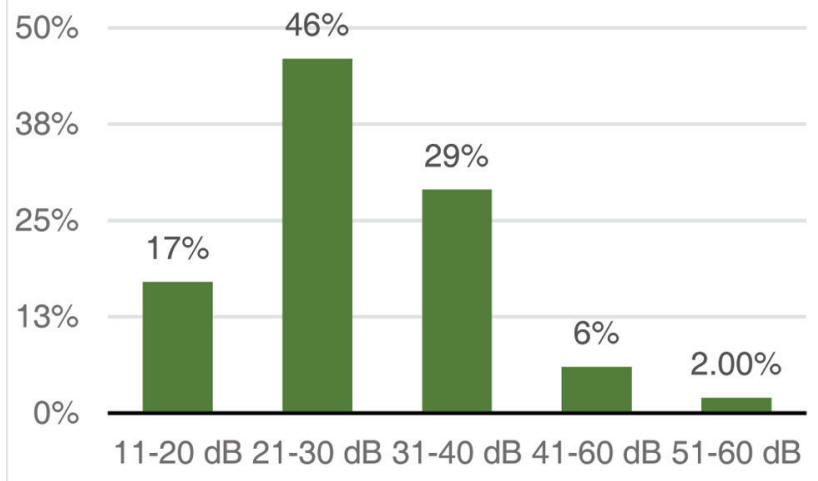

Fig. 3 Preoperative air bone gap. 
Eustachian catarrh and one patient with otitis media with effusion), and one patient with reperforation. Out of 16 patients in wet ears, who did not have hearing improvement, two patients had upper respiratory tract infections (two patients with Eustachian catarrh), two patients with tympanosclerosis and one patient with reperforation ( - Table 7 ).

Postoperatively, none of the patients had complications such as facial nerve palsy, change in taste, and tinnitus.

\section{Discussion}

Chronic suppurative otitis media is a condition characterized by chronic inflammation of the mucoperiosteal lining of middle ear cleft. The tubotympanic type is more common and characterized by perforation of the pars tensa of tympanic membrane. This perforation primarily results from middle ear infections, trauma, and iatrogenic causes. Patients presents with ear discharge and decreased hearing. Spontaneous closure of chronic perforation of tympanic membrane is uncommon and surgical treatment is necessary to close the perforation. The aim of the surgery is to eradicate the disease and restore hearing.

Berthold was the one who coined the term myringoplasty and used a thick skin graft, ${ }^{4}$ while Wullstein ${ }^{5}$ and Zollner ${ }^{6}$ used a split skin graft. In 1980s, most surgeons were convinced that mesoderm-originated grafts, such as perichondrium, fascia, vein, and fat tissue were advantageous. ${ }^{7}$ Several factors such as site and size of the perforation, technique, approach, surgeons experience, status of the contralateral ear, type of graft, age of the patient, and condition of the operated ear may affect the outcome of successful myringoplasty. ${ }^{8-13}$ In our study, 140 cases of tubotympanic type of CSOM with dry and wet ears were studied longitudinally with a postoperative follow-up of 1 year. This study included males and females in the ratio of 1:1.1; this was comparable with some studies that reported equal cases of both sexes. ${ }^{14}$

In the present study, only temporalis fascia was used as graft material. In the present study, the mean age was 37.6 that was comparable with the study conducted by Booth with the average age being 33.7 years. ${ }^{15}$ In our study, age did not play any effect on the outcome of myringoplasty, similar to the study conducted by Booth. ${ }^{15}$ Griffin ${ }^{16}$ classified size of the perforation into four grades: grade 1: perforation involving less than one quadrant of pars tensa, grade 2: involving from one quadrant to two quadrants, Grade 3: involving more than two quadrants and up to three quadrants, and Grade 4: involving more than three quadrants of pars tensa. In our study, maximum number of patients had medium size perforation (44\%), which was comparable with the study by Sharma. ${ }^{17}$

The mean preoperative $\mathrm{AB}$ gap was $28.6 \mathrm{~dB}$ in dry ears and $29.6 \mathrm{~dB}$ in wet ears. This was comparable with the study by Naderpour et al..$^{18}$ Albera et al examined the effect of factors such as age, sex, ear discharge, status of the contralateral ear, hearing loss, and surgical technique on the outcome of tympanoplasty. They finally concluded surgical technique to be the most effective factor on the final results of tympanoplasty. ${ }^{13}$ Similarly, in this study, factors such as age, sex, and ear discharge had no impact on the outcome of tympanoplasty statistically.

Table 5 Preoperative and postoperative air bone gap in dry and wet ears

\begin{tabular}{|c|c|c|c|c|c|}
\hline \multirow[t]{2}{*}{ Ear status } & \multirow[t]{2}{*}{ Preoperative $A B$ gap (dB) } & \multicolumn{3}{|c|}{ Postoperative AB gap (dB) } & \multirow[t]{2}{*}{ Results } \\
\hline & & 3rd month & 6th month & 1 year & \\
\hline Dry ear & 28.6 & 17.4 & 14.08 & 11.34 & $\begin{array}{l}\text { Friedmann } \\
\text { test- } 179.026 \\
p=0.0001\end{array}$ \\
\hline Wet ear & 29.6 & 20.64 & 16.94 & 14.4 & $\begin{array}{l}\text { Friedmann } \\
\text { test- } 178.763 \\
p=0.0001\end{array}$ \\
\hline
\end{tabular}

Table 6 Postoperative hearing improvement

\begin{tabular}{|l|l|l|l|l|}
\hline \multirow{2}{*}{ Hearing } & \multicolumn{2}{|c|}{ Dry ears } & \multicolumn{2}{c|}{ Wet ears } \\
\cline { 2 - 5 } & cases & percentage & cases & percentage \\
\hline Improved & 61 & $87.14 \%$ & 54 & $77.14 \%$ \\
\hline $\begin{array}{l}\text { Not } \\
\text { Improved }\end{array}$ & 9 & $12.86 \%$ & 16 & $22.86 \%$ \\
\hline
\end{tabular}

Table 7 Postoperative status of the ear

\begin{tabular}{|l|l|l|l|}
\hline $\begin{array}{l}\text { Postoperative } \\
\text { status }\end{array}$ & Third month & Sixth month & One year \\
\hline Myringitis & 14 & 12 & 0 \\
\hline Otomycosis & 2 & 4 & 0 \\
\hline Granulations & 3 & 3 & 0 \\
\hline Lateralized drum & 1 & 1 & 1 \\
\hline
\end{tabular}

Postoperative Graft Uptake between Dry and Wet Ears

The success rate of graft uptake between dry and wet ears after tympanoplasty in our study was $98.5 \%$, which is higher as compared with other studies in which success rates ranged from 82 to $98 \%{ }^{14,19}$ Also, the graft uptake rate was equal in both wet and dry ears. Vijayendra et $\mathrm{al}^{20}$ stated that the graft incorporation rate was better in wet ears than in dry ears. This can be attributed to lots of inflammatory cells and blood vessels in the remaining membranes of wet ears in contrary to the marginalized blood vessels in dry and atrophic membranes in dry ears, which is contrary to our study. Autologous temporalis muscle fascia is the graft of choice for this procedure ${ }^{21}$ for its superior tissue quality, its ready availability in the operative field, low basic metabolic rate (BMR), and excellent results in myringoplasty. ${ }^{22}$

Many studies reported that a discharging ear at the time of surgery has an effect on the outcome of myringoplasty both 
positively and negatively. It is difficult to control all variables that play a role in determining the outcome of myringoplasty. ${ }^{23}$ Gersdorff et $\mathrm{al}^{24}$ and Pignataro et $\mathrm{al}^{9}$ found better outcome of myringoplasty when operated on a dry ear and recommended medical treatment of discharging ears to control the infection and inflammation prior to surgery. In this study, the outcome was better in dry ears though the results were statistically insignificant. In the present study, there is no difference in dry and wet ears. Onal et $\mathrm{al}^{10}$ reported that myringoplasty will be more successful if the ear has been dry for longer periods although the result was statistically insignificant. Similarly, in the present study, the duration of preoperative dry period did not show any effect on the outcome of dry myringoplasty. Noh and Lee stated that there is no significant relationship between vascularization time of the graft and status of middle ear mucosa (dry and wet), ${ }^{25}$ which were comparable with the present study.

\section{Graft Uptake by Underlay Technique}

In 1961, Storrs followed by Patterson described the undersurface fascia technique. Raj and Tripathi who operated on patients with wet ears showed closure of perforation in $84 \%$ of patients. ${ }^{26}$ Our results are better than the abovementioned study. In 1987, Ophir et al in their study in pediatric population reported a success rate of $79 \%{ }^{27}$ James. L. Sheehy and Michael G. Glasscock in 1967 had a success rate of $97.5 \%$ after myringoplasty.

Shaikh et al observed the results of myringoplasty by underlay technique in dry ear patients and concluded that $81 \%$ of the patients had successful graft uptake and the factors such as age, sex and size of perforation had no effect on the results of myringoplasty significantly. ${ }^{28}$ In our study, the graft uptake rate was higher (98.5\%) than the study mentioned previously and the factors such as age and sex did not have any impact on the outcome. These results are comparable with other studies in which the success rates ranged from $35 \%$ to $95 \% 29,30$ (-Table 8 ).

\section{Postoperative Hearing Outcome}

Improvement in hearing is important in addition to clearance of the disease. We compared the hearing results between wet and dry ears after tympanoplasty. Initially, air conduction threshold was used as the bench mark to determine the improvement in hearing outcome in any surgical procedure. However, further studies stated that closure of air bone gap

Table 8 Graft uptake rate in various studies in dry and wet ears

\begin{tabular}{|c|c|c|}
\hline Author & $\begin{array}{l}\text { Wet ears } \\
\text { (\%) }\end{array}$ & Dry ears (\%) \\
\hline Sheehy and Anderson ${ }^{30}$ & $98 \%$ & $96.6 \%$ \\
\hline Glasscock et al ${ }^{19}$ & $92.7 \%$ & $93.1 \%$ \\
\hline Fadl $^{37}$ & $83.3 \%$ & $84.6 \%$ \\
\hline Pothala et al, 2018 & $98.5 \%$ & $98.5 \%$ \\
\hline Nagle et $\mathrm{al}^{35}$ & $74 \%$ & $88 \%$ \\
\hline Mills et $a^{23}$ & $82 \%$ & $83 \%$ \\
\hline
\end{tabular}

is better in judging the hearing outcome, which was also supported by Harder et al. ${ }^{31}$ The following points support the view of closure of air bone gap as better parameter in analyzing the improvement in hearing postoperatively after tympanoplasty. Air bone gap is more informative and gives the quantity of hearing improvement. In cases with longterm follow-up, there might be chances of reduced hearing due to sensorineural component in presbycusis in relation to patients age. The air bone gap remains small and thus a better parameter in judging the hearing outcome postoperatively. The difference between preoperative and postoperative air bone gap of $10 \mathrm{~dB}$ was taken as the criterion for improvement in hearing in the present study. According to this criterion, $82.14 \%$ patients had improvement in hearing.

In this study, out of 70 dry ears, 61 patients (87.14\%) had improvement in hearing and out of 70 wet cases, 54 patients (77.14\%) had improvement in hearing. These results are comparable with the studies in the literature. ${ }^{32-34}$ The mean postoperative air bone gap is $11.34 \mathrm{~dB}$ in dry ears and 14.4 dB in wet ears, which were comparable with the study by Naderpour et al. ${ }^{18}$ Although there is statistically significant improvement in hearing in both wet and dry ears separately, on comparison, there is no statistically significant difference between the two groups of wet and dry tympanoplasty.

These results were comparable with the study conducted by Nagle et al..$^{35}$ The overall improvement in hearing in this study is $82.14 \%$, which was comparable with the study conducted by Bennet ${ }^{36}$ (- Table 9).

In this study, postoperatively, there were conditions such as myringitis, otomycosis, and granulations. At the end of 1 year, all cases presented with dry ear. Those patients with the above conditions who had significant improvement in hearing, this improvement was possible because of meticulous antibiotic coverage in the postoperative period with the strict postoperative care and regular aural toilet during follow-ups.

\section{Conclusion}

Factors such as age, sex, and status of the contralateral ear and wet ear did not have any impact on the postoperative graft uptake of tympanoplasty. There was no difference in the graft uptake between the dry and wet ears, and there was no statistically significant difference between hearing improvement in both and wet ears.

\section{Conflict of Interest}

None declared.

Table 9 Hearing improvement in various studies in dry and wet ears

\begin{tabular}{|l|l|l|}
\hline Author & \multicolumn{2}{|l|}{ Hearing improvement } \\
\hline & Dry ears & Wet ears \\
\hline Hosney et $\mathrm{al}^{3}$ & $92.3 \%$ & $91.3 \%$ \\
\hline Pothala et al, 2018 & $87.14 \%$ & $77.14 \%$ \\
\hline
\end{tabular}




\section{References}

1 Merchant SN, McKenna MJ, Rosowski JJ. Current status and future challenges of tympanoplasty. Eur Arch Otorhinolaryngol 1998;255(5):221-228

2 Dhingra PL. Cholesteatoma and chronic otitis media, Diseases of ear, nose and throat 5th ed. 2010:75-83

3 Hosney S, El-Anwar M, Abdelhady M, Khazbak A, El-Feky A. Outcome of myringoplasty in wet and dry ears. Int Adv Otol 2014;10(3):256-259

4 Berthold E. Uebermyringoplastik. Wier Med Bull 1878;1:627

5 Shimada T, Lim DJ. The fiber arrangement of the human tympanic membrane. A scanning electron microscopic observation. Ann Otol Rhinol Laryngol 1971;80(2):210-217

6 Zollner F. The principles of plastic surgery of the sound-conducting apparatus. J Laryngol Otol 1955;69(10):637-652

7 Tarasov DI. Disease of the middle ear. M Medicine 1988; 66:1076-1095

8 Sergi B, Galli J, De Corso E, Parrilla C, Paludetti G. Overlay versus underlay myringoplasty: report of outcomes considering closure of perforation and hearing function. Acta Otorhinolaryngol Ital 2011;31(6):366-371

9 Pignataro L, Grillo Della Berta L, Capaccio P, Zaghis A. Myringoplasty in children: anatomical and functional results. J Laryngol Otol 2001;115(5):369-373

10 Onal K, Uguz MZ, Kazikdas KC, Gursoy ST, Gokce H. A multivariate analysis of otological, surgical and patient-related factors in determining success in myringoplasty. Clin Otolaryngol 2005;30(2):115-120

11 Denoyelle F, Roger G, Chauvin P, Garabedian EN. Myringoplasty in children: predictive factors of outcome. Laryngoscope 1999;109(1):47-51

12 Westerberg J, Harder H, Magnuson B, Westerberg L, Hydén D. Ten-year myringoplasty series: does the cause of perforation affect the success rate? J Laryngol Otol 2011;125(2):126-132

13 Albera R, Ferrero V, Lacilla M, Canale A. Tympanic reperforation in myringoplasty: evaluation of prognostic factors. Ann Otol Rhinol Laryngol 2006;115(12):875-879

14 Caylan R, Titiz A, Falcioni M, et al. Myringoplasty in children: factors influencing surgical outcome. Otolaryngol Head Neck Surg 1998;118(5):709-713

15 Booth JB. Myringoplasty-factors affecting results. Final report. J Laryngol Otol 1973;87(11):1039-1084

16 Griffin WL Jr. A retrospective study of traumatic tympanic membrane perforations in a clinical practice. Laryngoscope 1979;89(2 Pt 1):261-282

17 Sharma M, Singh P, Goel M, Kotwal D, Kapoor M. Dry versus wet myringoplasty: our experience. Int J Dent Med Res 2015;1(6):47-50

18 Naderpour M, Shahidi N, Hemmatjoo T. comparison of Tympanoplasty results in dry and wet ears. Iran J Otorhinolaryngol 2016;28(86):209-214

19 Glasscock ME III, Jackson CG, Nissen AJ, Schwaber MK. Postauricular undersurface tympanic membrane grafting: a follow-up report. Laryngoscope 1982;92(7 Pt 1):718-727
20 Vijayendra H, Rangam CK, Sangeeta R. Comparative study of tympanoplasty in wet perforation $\mathrm{v} / \mathrm{s}$ totally dry perforation in tubotympanic disease. Indian J Otolaryngol Head Neck Surg 2006;58(2):165-167

21 Glasscock ME III, House WF. Homograft reconstruction of the middle ear. A preliminary report. Laryngoscope 1968;78(7):1219-1225

22 Pal MB, Khan N. Incidence of complications in temporal bone due to cholesteatoma. 1995;10(4):109-111

23 Mills R, Thiel G, Mills N. Results of myringoplasty operations in active and inactive ears in adults. Laryngoscope 2013;123(9):2245-2249

24 Gersdorff M, Garin P, Decat M, Juantegui M. Myringoplasty: long-term results in adults and children. Am J Otol 1995;16(4):532-535

25 Noh H, Lee DH. Vascularisation of myringo-/tympanoplastic grafts in active and inactive chronic mucosal otitis media: a prospective cohort study. Clin Otolaryngol 2012;37(5):355-361

26 Raj A, Tripathi V. Review of patients undergoing wet myringoplasty. Indian J Otol 1999;5(3):134-136

27 Ophir D, Porat M, Marshak G. Myringoplasty in the pediatric population. Arch Otolaryngol Head Neck Surg 1987;113(12):1288-1290

28 Shaikh AA, Onali MAS, Shaikh SM, Rafi T. Outcome of tympanoplasty type-I by underlay technique. J Liaquat Uni Med Health Sci. 2009;8(1):80-84

29 Bluestone CD, Cantekin EI, Douglas GS. Eustachian tube function related to the results of tympanoplasty in children. Laryngoscope 1979;89(3):450-458

30 Sheehy JL, Anderson RG. Myringoplasty. A review of 472 cases. Ann Otol Rhinol Laryngol 1980;89(4 Pt 1):331-334

31 Harder H, Jerlvall L, Kylén P, Ekvall L. Calculation of hearing results after tympanoplasty. Clin Otolaryngol Allied Sci 1982;7(4):221-229

32 Umapathy N, Dekker PJ. Myringoplasty: is it worth performing in children? Arch Otolaryngol Head Neck Surg 2003;129(10):1053-1055

33 Karela M, Berry S, Watkins A, Phillipps JJ. Myringoplasty: surgical outcomes and hearing improvement: is it worth performing to improve hearing? Eur Arch Otorhinolaryngol 2008;265(9):1039-1042

34 Perkins R, Bui HT. Tympanic membrane reconstruction using formaldehyde-formed autogenous temporalis fascia: twenty years' experience. Otolaryngol Head Neck Surg 1996;114(3):366-379

35 Nagle SK, Jagade MV, Gandhi SR, Pawar PV. Comparative study of outcome of type I tympanoplasty in dry and wet ear. Indian J Otolaryngol Head Neck Surg 2009;61(2):138-140

36 Bennett RJ. Observations on drumhead repair in tympanoplastic surgery. J Laryngol Otol 1971;85(8):745-772

37 Fadl FA. Outcome of type- 1 tympanoplasty. Saudi Med J 2003;24(1):58-61 